\title{
Credit Card Debt in Kota Damansara, Selangor: An Investigation of Credit Card Debt Determinants and Factors
}

\author{
Mahiswaran Selvanathan, PhD (Corresponding author) \\ SEGi University, Malaysia \\ Email: mahiswaran@gmail.com
}

Dineswary Nadarajan

SEGi University, Malaysia

Yong Wei Yee

SEGi University, Malaysia

Faria Rabbi

SEGi University, Malaysia

Received: July 15, 2016 Accepted: September 05, 2016 Published: October 03, 2016 doi:10.5296/ijhrs.v6i3.10091 URL: http://dx.doi.org/10.5296/ijhrs.v6i3.10091

\begin{abstract}
This paper explores factors influencing credit card debts in Kota Damansara, Selangor, Malaysia. Specifically, variables such as attitude, income, financial knowledge and bank policies are examined. The questionnaire in the study was distributed among 120 credit card holders. The study serves as guide researchers to extend the research work covering more variables in different economies. The data is collected using simple random sampling techniques. The results indicate that attitude, income, financial knowledge and bank policies have significant relationship with credit card debts. The contribution to this result can help to developing market economies or even developed countries where credit card debt is high. It gives awareness to the banker on understanding their credit card consumers, as well as providing insights to the credit card holders.
\end{abstract}

Keywords: Credit Card Debits, Attitude, Income, Financial Knowledge and Bank policy. 


\section{Introduction}

Credit cards, like Visa, MasterCard, American Express, Diners Club and others are financing for consumer in short term lines. Depending on the conditions, credit cards are a guarantee's consumption of money obtain in advance and thus return at the specific periods time (Rasiah \& Masuod, 2013). The history of credit cards actually began as early as the $18^{\text {th }}$ century in Europe. Since the 1920's, credit cards existed on the United States on individual enterprises such as hotels, department stores and oil companies, which began issuing credit cards to their consumers (Jusoh \& Yen Lin, 2012). In the 1950's, the entertainment and travel card appeared as third-party card. Finally, the bankcard created. In the 1960's, the first bankcard which is Visa card was launched by Bank Americard (Ramayah, Noor, \& Nasurdin, 2002). Credit cards are well-known in developed countries decades ago, such as Malaysia. In Malaysia, the use of cheque is fairly limited, thus plastic card especially credit cards play an important role in the transactions that carried out daily (Ramayah et al., 2002). The purpose of credit card firstly introduced is to assist individuals for paying of goods and other household services in a convenient way. However, credit cards later treat as a source of long term borrowings; this is because individuals are trying to keep pace of their household expenses. Nevertheless, credit card holders may gain an unsecured loan at a relatively reasonable rate for financial institutions while having a good rating in their credits. It is essential as the Annual Percentage Rate (APR) based on the debt of credit card is higher compared to others. As stated in Credit Action, the average rate of APR are amounted to 17.42 percent (\%) charged on credit card balances, which show that it is $120 \%$ higher than personal loans (Ahmad \& Omar, 2013).

In addition, credit card is considered as a kind of payment that is broadly utilized by consumers to purchase goods and services in terms of credit card dept. The growth of credit card usage is relating to the growth of other types of consumer credits, for example, personal loans and other more. Even though credit card is able to motivate consumer spending and provide flexibility to consumers, it likewise has its frustration (Warwick \& Mansfield, 2000). The development of financial services has increased nowadays, thus increases the credit availability and usage, and directly increases the consumer debts, especially in terms of credit card debts (Omar, Rahim, Wel, \&Alam, 2014). According to Soman (2001), the credit card users are usually to make additional purchases and also tend to spend on. Therefore, they hold a large balance that gathers up in their credit card because they are usually paying only the minimum required amount by the issuer (Omar et al., 2014).

\section{Research Objectives}

The main objectives of this research are divided into the following major part, which are:

1. To discover the relationship between attitude and credit card debts.

2. To discover the relationship between income and credit card debts.

3. To discover the relationship between financial knowledge and credit card debts.

4. To discover the relationship between bank policies and credit card debts. 


\section{Literature Review}

\subsection{Credit Card Debts}

Credit card debt is one of the consumer debts. Consumer debt is the outstanding amount on credit cards, car loans, other personal loans, instalment debts, and unpaid bills. In short, credit card debt is the amount of outstanding that individual does not pay off after purchasing through the use of credit card (Chawla \& Uppal, 2012). The use of credit card allows greater consumption smoothing, and to some extent, improve the expenditure. Although there is a high rate of credit card interest, it has a less effect on household's income because the credit card is able to use to mitigate this impact. In addition, credit cards view as financing to cardholders in more convenient way. However, there are some credit card user misuses their cards (Ahmad \& Omar, 2013). The convenience users view credit card as an instrument to facilitate the exchange. While, instalment users are credit card holders that pay a less amount compared to its due balance and hence have to pay for interest on balance unpaid amount. The instalment users view credit cards as debt instrument (Danes \& Hira, 1990). According to, Omar et al. (2014), many credit card holders in Malaysia display compulsive spending behaviour, while the easy accessibility to credit card, this behaviour leads to excessive debts among Malaysians.

\subsection{Attitude}

In order to identify the raise of credit card debts, it is important to recognize a person's attitudes in terms of credit, money, debt and spending behaviour toward their lifestyles (Arabzadeh \& Aghaeian, 2015). According to Pachauri (2001), attitude is getting from the word of Latin, which is "aptus", mean of "fitness" or "adaptedness". Pachauri (2001) defined attitudes as it can be like and dislike, main features that distinguish attitude against other concepts is its nature of evaluation or affective, and attitudes are the core of favourite or verse vice on particular people, groups, status, goals and intangible ideas. According to Fishbein and Ajzen (1977), attitude is supporting or opposes to affect the amount of certain objects. As Roberts and Jones (2001) stated, attitude is a subjective object, because of its multi-faceted. Therefore, it is considered that the attitude to consumer toward money can be affecting the debts of credit card. The introduction to several dimensions of money was established with the purpose of allowing individuals to have better understanding on attitude to money. Tang (1993) introduced a scale called Money Ethic Scale and stated that it is primarily in three aspects. First, money stands for the achievement of a person in community or the sign of success. Second, money can help people to gain respect from community because it is a sign of status. Third, the power of money refers to a sense to an individual. Tang (1993) refers the aspects as standard cognitive components in attitudes toward money.

\subsection{Income}

Income is the amount of money gain in a specific period of time that converts from labour or services, merchandise sales or property, or profit from financial investments (Chawla \&Uppal, 2012). Apart from that, income is equal to consumption level which is likely to continue indefinitely out of the current income of the capitalized value, which is equal to the end of the 
week as well-off at the beginning (Asheim, 1994). In terms of demographic variables, the impact on income was considered as the most important factor that significant affects the credit card debt. The higher the income, the higher the number of an individual possesses a credit card (Kaynak and Harcar, 2001). Besides that, higher household income was found to be more frequently to use credit cards compared to the low income families. According to Wasberg, Hira and Fanslow (1992), there are positive relationship between the amount of credit card debt and net income. Conversely, Danes and Hira (1990) argued that the low income families and middle-income families used to depend more on credit card as compared to high-income families. This is because these persons are less privileged economically. Therefore, credit cards are view as an instalment of credit for them because they unable to make loans from banks of an affordable rate (Kaynak\&Harcar, 2001). Devlin, Worthington and Gerrard (2007) stated that the household who has higher income used to hold more credit cards. In other words, because of higher income level, they have the ability to pay off the credit card debts (Scott, 2007). However, the category of the lowest income families are always thinking wisely on anything related to the decision on money (Slocum \& Matthews, 1970).

\subsection{Financial Knowledge}

Financial knowledge is the ability of an individual to read, analyse, manage and communicate with their condition of finance that influence material well-being, which identify financial choice, discussing of any issues of financial or money without uncomfortable, and the ability of planning for the future and coping with the daily life activities which affecting the financial decisions (Huston, 2010). According to French and McKillop (2014), financial knowledge is the characteristics that combine with awareness, knowledge, skill, attitude and behaviour in order to make financial decision. In the context, knowledge is the understanding of personal and broader financial transaction capability, skill is the ability to apply knowledge in their daily life, attitude and behaviour represents the self-confidence to make appropriate financial decisions. Next, Servon and Kaestner (2008) defined financial knowledge as the ability of an individual on the understanding of financial concepts. In other words, financial knowledge is knowledge and skills that can be used to manage financial resources in more effective way for lifetime financial security.

\subsection{Bank Policies}

In this study, bank policies represent the benefits of credit card holders from banks or non-banks, the payment policy they implied, and eligibility requirements to apply for a credit card. Because of the large number of competitors in the market of credit card, many banks are struggling to provide continuous product improvement and innovation to build their own niche markets (Subramaniam \& Marimuthu, 2010). Benefits given payment policies provided by the bank significantly influence the spending and application of a credit card (Ming-Yen et al., 2013) some financial institutions practice award scheme will have the ability to change the credit card holder spending and debt. In the perspective of credit card issuer, they may benefit from a higher credit card interest charges penalties prescribed in credit card. However, it would due to credit card debts of the credit card holders do not pay back the money 
(Azman et al., 2015).

\section{Analysis}

\subsection{Correlation Analysis between the Dependent Variable and Independent Variables}

The results from Table 1 show the correlation between the dependent variable and independent variables, which are used to test the hypotheses in this study. Based on Table 2, credit card debt has shown a very high correlation with attitude. However, credit card debt has shown a high correlation between income, financial knowledge and bank policies. Moreover, attitude has shown a very high correlation between credit card debt, while the attitude has shown a high correlation between income, financial knowledge and bank policies. Furthermore, income has shown a high correlation between credit card debt and attitude. Nevertheless, income has shown a moderate correlation between financial knowledge, while there is a high correlation between bank policies.

In addition, financial knowledge has shown a high correlation between credit card debt, attitude. However, financial knowledge has shown a moderate correlation between income, and a high correlation between bank policies. Lastly, bank policies have shown a high correlation between credit card debt, attitude, income and financial knowledge. 


\section{Macrothink \\ International Journal of Human Resource Studies \\ ISSN 2162-3058 \\ 2016, Vol. 6, No. 3}

Table 1: Correlations between the variables

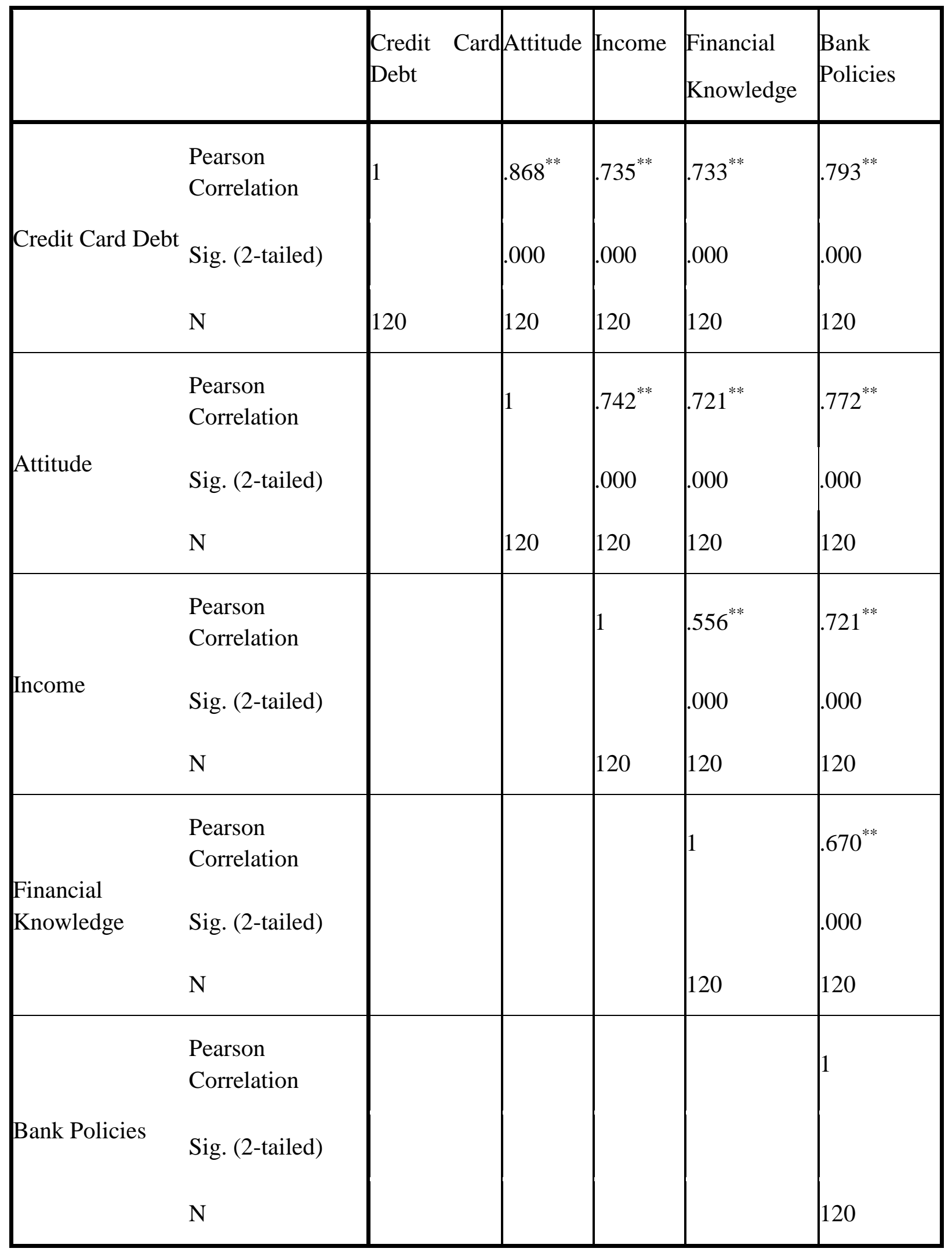

**. Correlation is significant at the 0.01 level (2-tailed). 


\section{Macrothink \\ International Journal of Human Resource Studies \\ ISSN 2162-3058 2016, Vol. 6, No. 3}

\subsection{Multiple Regression Analysis}

In this study, multiple regression analysis was conducted to determine the relationship between the dependent variable and each of the independent variables so as to test the hypotheses. Based on Table 2, the 'R Square' for factors influencing credit card debts (attitude, income, financial knowledge and bank policies) is 0.809 . This represents that there i $80 \%$ of respondents contribute to the variable of factors influencing credit card debts.

The extent of the arrangement of strengths of factors influencing credit card debts (attitude, income, financial knowledge and bank policies) that contribute to credit card debts are attitude $(\mathrm{B}=.494)$, bank policies $(\mathrm{B}=.210)$, financial knowledge $(\mathrm{B}=.166)$ and income $(\mathrm{B}=.125)$.

For each variable, the value of significant will indicate whether these variables contributed significantly to the equation. The hypothesis is accepted while the value is significant with less than .05 . Conversely, the hypothesis is rejected while the value is significantly where it is more than .05. Hence, the results of the hypotheses in this study are shown in Table 3.

Table 2: Multiple Regression Analysis between the Dependent Variable and Independent Variables

\begin{tabular}{|l|l|l|l|l|}
\hline Result & $\begin{array}{l}\text { Independent } \\
\text { Variables }\end{array}$ & $\begin{array}{l}\text { Standardized } \\
\text { Coefficients } \\
\text { Beta }\end{array}$ & $\begin{array}{l}\text { Significant } \\
\text { Value }\end{array}$ & $\mathbf{R}^{\mathbf{2}}$ \\
\hline \multirow{2}{*}{$\begin{array}{l}\text { Credit } \\
\text { Card } \\
\text { Debt }\end{array}$} & Attitude & .494 & .000 & .809 \\
\cline { 2 - 4 } & Income & .125 & .056 & \\
\cline { 2 - 4 } & Financial Knowledge & .166 & .007 & .004 \\
\cline { 2 - 4 } & Bank Policies & .210 & & \\
\hline
\end{tabular}


Table 3: Summary of Hypotheses Results

\begin{tabular}{|l|l|l|}
\hline Hypotheses Statements & $\begin{array}{l}\text { Significant } \\
\text { Value }\end{array}$ & Result \\
\hline $\begin{array}{l}H_{1} \text { There is a positive relationship between attitude and credit } \\
\text { card debts. }\end{array}$ & .000 & Accepted \\
\hline$H_{2}$ There is a positive relationship between income and credit & .056 & Rejected \\
card debts. & Accepted \\
\hline $\begin{array}{l}H_{3} \text { There is a positive relationship between financial } \\
\text { knowledge and credit card debts. }\end{array}$ & .007 & Accepted \\
\hline$H_{4}$ There is a positive relationship between bank policies and \\
credit card debts.
\end{tabular}

\section{Conclusion}

Credit card holders are usually the one that lead themselves into credit card debts. In this study, the findings of factors influencing credit card debts will help the credit card holders to reduce their debts level. As a result, credit card debts can be quickly mounted up while the credit card holders do not pay off their debts in full before the due date. Thus, credit card holders are able to know which factors that leads to credit card debts with the highest occupy. The attitude to credit card holders gains the highest correlation between the credit card debts. Therefore, for example, credit card debts holders may need to change their attitudes in order to reduce their debt level. In order to change or adjust their attitudes, financial counsellors are able to help the credit card debts holders to understand why they hold certain spending attitudes while having credit cards in hand. Furthermore, credit card holders are able to gain the benefits of paying low interest rate if they pay off the debts before the $0 \%$ interest rate deal runs out. Hence, it identified that this study serve to explain the credit card holders regarding to the effect of variables (attitude, income, financial knowledge and bank policies) to their debt level. Thereby, credit card holders may apply certain action on the specific variable so as to modify ego. First of all, the time bound in this study is limited, as it was given approximately three months to collect and analyse the data. Second, the sample size of this study is relatively small. Third, the sample size of geographical area of this study is comparatively small. As it was limited to the credit card holders in Kota Damansara, Selangor, this represents that the results indicated may not be generalized to others in other area. Fourth, this study found that income is a weak predictor for credit card debts, which remains an 
interesting issue to future research to examine. In recommendation, other factors should be determined as well, in order to identify the other possible impacts of credit card debts thus obtain the better and more accurate results. The inclusion of other variables such as demographics, psychological and socio-economic factors which are relevant to credit card spending and debt are warranted. Apart from that, in order to provide more comprehensive explanations, other potential factors are suggested exploring. Future researches may extend the scope to incorporate other conceivable components that may contribute to affect the credit card debts.

\section{References}

Ahmad, R. (2016). Credit Card Debt Management: A Profile Study of Young Professionals. Asia-Pacific Management Accounting Journal, 8(1).

Arabzadeh, E., \&Aghaeian, S. (2015). The relationship of usages and Management of credit cards on lifestyles and purchasing behaviours of Cardholders. International Journal of Management Research and Business Strategy, 4(3), 245-256.

Asheim, G. B. (1994). Net national product as an indicator of sustainability.The Scandinavian Journal of Economics, 96(2), 257-265.

Azman, N. S., Shari, A., Gazali, H. M., Abdullah, M. A., \& Khalil, N. M. (2015). Urban Household Credit Card Debt Behaviour in East Malaysia: A Conceptual Framework.

Chawla, R. K., \&Uppal, S. (2012). Household debt in Canada. Perspectives on labour and income, 24(2), 1 .

Danes, S. M., \& Hira, T. K. (1990). Knowledge, beliefs, and practices in the use of credit cards. Home Economics Research Journal, 18(3), 223-235.

Devlin, J. F., Worthington, S., \& Gerrard, P. (2007). An analysis of main and subsidiary credit card holding and spending. International Journal of Bank Marketing, 25(2), 89-101.

Fishbein, M., \&Ajzen, I. (1977). Belief, attitude, intention, and behavior: An introduction to theory and research.

French, D., \&McKillop, D. G. (2014). Financial literacy and over-indebtedness in low-income households. Available at SSRN 2505084.

Huston, S. J. (2010). Measuring financial literacy. Journal of Consumer Affairs, 44(2), 296-316.

Jusoh, Z., \& Lin, L. Y. (2012). Personal financial knowledge and attitude towards credit card practices among working adults in Malaysia. International Journal of Business and Social Science, 3(7).

Kaynak, E., \&Harcar, T. (2001). Consumers' attitudes and intentions towards credit card usage in an advanced developing country. Journal of Financial Services Marketing, 6(1), 
24-39.

Ming-Yen Teoh, W., Chong, S. C., \& Mid Yong, S. (2013). Exploring the factors influencing credit card spending behavior among Malaysians.International Journal of Bank Marketing, 31(6), 481-500.

Omar, N. A., Rahim, R. A., Wel, C. A. C., \& Alam, S. S. (2014). Compulsive buying and credit card misuse among credit card holders: The roles of self-esteem, materialism, impulsive buying and budget constraint. Intangible Capital, 10(1), 52-74.

Pachauri, M. (2001). Consumer behaviour: a literature review. The Marketing Review, 2(3), 319-355.

Ramayah, T., Nasser, N., Aizzat, M., \& Lim, H. C. (2002). Cardholders' attitude and bank credit card usage in Malaysia: An exploratory study. Asian Academy of Management Journal, 7(1), 75-102.

Rasiah, D., \&Masuod, M. S. (2013). The Flexible Alternative Consumer Financing in Malaysia: Credit Cards. Journal of Social and Development Sciences, 4(3), 147.

Roberts, J. A., \& Jones, E. (2001). Money attitudes, credit card use, and compulsive buying among American college students. Journal of Consumer Affairs, 35(2), 213-240.

Scott, R. H. (2007). Credit Card Use and Abuse: A Veblen ianAnalysis.Journal of Economic Issues, 41(2), 567-574.

Servon, L. J., \&Kaestner, R. (2008). Consumer financial literacy and the impact of online banking on the financial behavior of lower-income bank customers. Journal of Consumer Affairs, 42(2), 271-305.

Soman, D. (2001). Effects of payment mechanism on spending behavior: The role of rehearsal and immediacy of payments. Journal of Consumer Research, 27(4), 460-474.

Slocum Jr, J. W., \& Mathews, H. L. (1970). Social class and income as indicators of consumer credit behavior. The Journal of Marketing, 69-74.

Subramaniam, R., \&Marimuthu, M. (2010). Bank credit card and the selection criteria: An exploratory study. African Journal of Business Management, 4(16), 3463.

Tang, T. L. P. (1993). The meaning of money: Extension and exploration of the money ethic scale in a sample of university students in Taiwan. Journal of Organizational Behavior, 14(1), 93-99.

Warwick, J., \& Mansfield, P. (2000). Credit card consumers: college students' knowledge and attitude. Journal of Consumer Marketing, 17(7), 617-626.

Wasberg, C. A., Hira, T. K., \&Fanslow, A. M. (1992). Credit card usage and consumer debt burden of households. Journal of Consumer Studies \& Home Economics, 16(1), 19-32. 


\section{Macrothink}

International Journal of Human Resource Studies

ISSN 2162-3058

\section{Copyright Disclaimer}

Copyright for this article is retained by the author(s), with first publication rights granted to the journal.

This is an open-access article distributed under the terms and conditions of the Creative Commons Attribution license (http://creativecommons.org/licenses/by/3.0/). 